\title{
РОЛЬ ЦИФРОВОГО КОНТЕНТ-НАВЧАННЯ В СОЦІАЛІЗАЦІЇ СТУДЕНТІВ-МАЙБУТНІХ ФІЛОЛОГІВ
}

\author{
Валентина Коваленко \\ старший викладач кафедри іноземних мов \\ ДВНЗ «Донбаський державний педагогічний університет», \\ Слов'янськ, Україна \\ ORCID 0000-0002-7391-3746 \\ valentina.kovalenko1204@gmail.com
}

\begin{abstract}
Анотація. У статті висвітлено роль та місце цифрового контент-навчання в процесі соціалізації майбутніх студентів-філологів. Автор порушує проблему невідповідності нових вимог до підготовки студентів вищих навчальних закладів та їх соціалізації під час навчання. Наголошується на необхідності урахування тенденцій цифровізації під час підготовки фахівців філологічних спеціальностей. Проведено аналіз основних принципів цифровізації в комунікаційній стратегії університетської освіти. Автор актуалізує потребу формування у студентів цифрової культури, яка пов'язується із здатністю особи продуктивно соціалізуватися в освітньому просторі вищого навчального закладу. Такий процес можливий, за переконанням дослідниці, проте потребує низки перетворень. Автор наголошує на необхідності вдосконалення процесу соціалізації студентів, враховуючи тенденції інформатизації та цифровізації суспільства в реформуванні освіти.
\end{abstract}

Ключові слова: цифровізація освіти; процес соціалізації; вища освіта.

Постановка проблеми в загальному вигляді. Інтеграція процесу цифровізації та нових форм комунікації створює нове соціокультурне середовище, у межах якого здійснюються контакти між різними суб'єктами інформації та комунікації.

На стику другого й третього тисячоліть практично здійснений перехід від індустріальної цивілізації до інформаційної, що стало поштовхом для появи нового комплексу наукових дисциплін і напрямків, які стануть науковою базою інформаційної цивілізації. Не враховувати цього в реформуванні освіти неприпустимо. Тому в системі соціалізації особистості повинні домінувати комунікаційні компоненти: жити і працювати випускникам цієї системи доведеться вже в інформаційній цивілізації, де пріоритетну роль відіграватимуть фундаментальні знання про інформаційні процеси в природі і суспільстві. Для цього в освітньому процесі мають фігурувати насамперед такі засоби навчання, освітні технології і методики, які дозволяють виходити на системний рівень пізнання дійсності, бачити і використовувати механізми соціалізації особистості.

Проблема, порушена в статті, полягає у розбіжності між підвищенням вимог до ефективності та прискорення соціалізації індивідуума і недостатнім

Професіоналізм педагога: теоретичні й методичні аспекти. Методичні матеріали до проєкту «Цифровий освітній простір: українсько-польський досвід». - Слов’янськ, 2021. 
застосуванням взаємодії соціального-комунікаційного простору вищого навчального закладу, його цифрового складника і недостатньою реалізацією його на практиці. У роботі навчальних закладів процес соціалізації особистості залишається прерогативою виховання, яке за умови традиційної освітньої моделі набуло характеру другорядності, поступившись першочерговістю процесу навчання. Як результат, більшість випускників вищих навчальних закладів, зокрема філологи, мають слабко сформовані життєві компетенції, нерозвинуті соціальні здібності, не здатні до самореалізації в соціумі та в професійному середовищі.

Аналіз останніх досліджень і публікацій. Інформатизація української освіти наразі має міцну нормативно-правову державну підтримку. Серед державних документів останніх років, що становлять забезпечення освіти в інформаційному суспільстві: Закони України «Про вищу освіту», «Про Національну програму інформатизації»; Розпорядження Кабінету Міністрів України «Про схвалення Концепції розвитку цифрової економіки та суспільства України на 2018-2020 роки», «Про схвалення Стратегії розвитку інформаційного суспільства в Україні», «Положення про електронні освітні ресурси», «Положення про електронний підручник», «Положення про Національну освітню електронну платформу»; проєкт «Цифрова адженда України - 2020», «Концепція Нової української школи» та ін.

Дослідженню різних аспектів цифрового контент-навчання, формуванню цифрової культури як феномену інформаційного суспільства присвячені наукові праці Л. Гаврілової, О. Крапивенко, Т. Браун. Р. Мартін, Д. Роулс.

У наукових розвідках останніх років репрезентовано низку питань, дотичних до проблеми нашого дослідження, зокрема: формування інформаційної культури (інформаційно-цифрової, цифрової) (О. Базелюк, Н. Воронова, С. Лазоренко).

Проблеми використання інформаційно-комунікаційних (цифрових) технологій в процесі соціалізації студентів, впливу цифрової культури на формування соціальних цінностей майбутніх фахівців, створення цифрового соціально-комунікаційного освітнього простору практично залишаються поза увагою дослідників.

Формулювання цілей статті (постановка завдання). Метою дослідження $є$ обгрунтування необхідності застосування цифрового контентнавчання як складника соціалізації в процесі підготовки майбутніх філологів.

Результати дослідження. Цифрове контент-навчання передбачає вміння використовувати цифрові технології для підтримки соціальної інтеграції, 
активного громадянства, творчості, співпраці з іншими людьми та досягнення особистих і соціальних цілей.

Необхідною передумовою соціальної стабільності і успішного функціонування будь-якого суспільства $є$ наявність загальновизнаної системи цінностей, що містить спільні ідеали, символи, мораль, традиції, норми поводження та ін. Завдяки наявності осоціально-комунікаційного простору вищого навчального закладу здійснюється соціалізація студентів, формується світогляд, форми поведінки, виробляється соціальне ядро особистості. Соціокультурне середовище університету формує специфічний простір, в якому проходить процес соціалізації студента, формується особистість майбутнього фахівця. Воно охоплює різноманітні канали і форми навчання, відтворює i трансформує соціальні цінності і цінності закладу вищої освіти. Соціальні цінності є фундаментом створення світогляду молоді. В процесі соціалізації формуються соціальні цінності і реалізуються в процесі життєдіяльності й підтверджуються або заперечуються життєвим досвідом. У свідомості молоді знаходять висвітлення зміни, що відбуваються в суспільстві та які визначають зміни в системі ціннісних орієнтацій студентства. Це і соціально-психологічний клімат у студентській групі; сімейне оточення; доступ до засобів освіти й культурних досягнень суспільства; релігійні переконання та інші умови, що впливають на особистість майбутнього фахівця.

Варто зазначити, що комунікація для майбутнього вчителя-філолога є не тільки засобом, а й метою та завданням навчання. Формування особистісної сфери світосприйняття студента-філолога здійснюється не тільки під впливом цілеспрямованого освітньо-виховного процесу, але й специфічного соціальнокомунікаційного простору вищого навчального закладу. Комунікативні якості є ключовими у роботі вчителя-філолога, оскільки мова для нього є не тільки засобом здійснення взаємодії з учнями, а й предметом навчання.

Важливою для соціалізації студентів-філологів $є$ соціальна компетентність. В ній виокремлюється декілька компонентів:

- особистісний (здатність до самореалізації в обраній професії);

- діяльнісний (здатність до професійної діяльності);

- комунікативний (здатність до ефективного спілкування та взаємодії).

В процесі педагогічної комунікації ставляться мета і конкретні завдання, які вимагають свого вирішення. Процес комунікації складається з окремих актів, через які реалізуються основні функції комунікації:

- управлінська - пов'язана 3 успішністю функціонування певної організації та є генетично й структурно вихідною; 
- інформативна - пов'язана з обміном інформацією та науковим аналізом змісту інформаційних повідомлень;

- емотивна - пов'язана 3 емоційними переживаннями; фактична пов'язана із встановленням контактів.

За переконанням дослідників, особливістю комунікаційних процесів, що відбуваються в соціально-комунікаційному просторі вищого навчального закладу є:

1. Специфічний паралельний цифровий простір (електронна форма комунікації) зумовлює віртуальність комунікаційних процесів, коли електронне спілкування, на відміну від усної або документальної форми комунікації, відбувається в віртуальному інформаційному просторі глобальної комп’ютерної мережі.

2. Інтерактивність проявляється в розвитку гіпермедіа, що разом з масмедіа $\epsilon$ універсальним посередником комунікацій сучасного соціального спілкування в різних сферах суспільного життя.

3. Гіпертекст забезпечує глобальний характер спілкування і всі інформаційні потоки в єдиному інформаційному комунікаційному середовищі.

Сучасні наукові дослідження, зокрема, А. Шелестової (2013) тлумачать поняття "освітній простір" як феномен зустрічі та взаємодії людини 3 оточуючими iї елементами - носіями культури (освітнім середовищем), унаслідок чого відбувається їхнє осмислення та пізнання:

1. Освітній простір відображає систему соціальних зв'язків та відношень у галузі освіти, характер взаємовідношень суспільства й суспільних інститутів, пов'язаних із задоволенням освітніх потреб суспільства.

2. Освітній простір - структурована система педагогічних факторів, що забезпечують взаємодію, осмислення та пізнання (освоєння) особистістю в процесі іiі розвитку та становлення спеціально організованого педагогічного середовища.

3. Освітній простір - місце перетинання діяльності всіх учасників освітнього простору, де забезпечується використання та активізація їхнього творчого потенціалу.

4. Освітній простір завжди має певні особливості залежно від географії.

5. Освітній простір характеризується обсягом освітніх послуг, потужністю, інтенсивністю освітньої інформації, освітньою інфраструктурою (якісний i кількісний склад іiі елементів, їх розміщення в просторі та взаємодія) та функціонує на принципах взаємодії різних освітніх систем, породжених певною культурою). 
Інтеграція процесу стрімкого поширення інформації й нових форм комунікації створює нове соціокультурне середовище, у межах якого здійснюються контакти між різними суб’єктами інформації та комунікації.

Ці процеси мають стати стратегічними в комунікаційній політиці університетської освіти. Їхній розвиток повинен грунтуватись на таких принципах:

- єдність професійних цілей і завдань усіх учасників науково-освітнього процесу, різних підрозділів, служб незалежно від рівня їхньої інформатизації на цей момент;

- системність - збалансованість процесу інформатизації за напрямками та послідовність здійснюваних заходів;

- модульність - створення інформаційних систем різної складності, автономності та ступеня комп’ютеризації;

- технологічність - реальні економічні можливості університету й відповідність функцій університету та його кадрового потенціалу заявленому рівню інформатизації;

- динамізм - відповідність рівня інформатизації науково-освітнього процесу інформаційним потребам, які швидко змінюються, i технічним можливостям їх задоволення.

Сучасна інформаційна інфраструктура вищого навчального закладу може постійно змінюватися, вдосконалюватися, підсилюватися завдяки веб-сайтам, що виконують численні освітні, інформаційні, комунікаційні функції в соціумі.

Таким чином, дослідники, зокрема А. Шелестова (2013), розуміють цифрове середовище вищого навчального закладу як простір:

- нового типу, що формується в результаті нової глобальної соціальної революції, основою якої є безперервний розвиток та інтеграція інформаційних і комунікаційних технологій;

- у якому головною умовою розвитку суспільства $є$ знання, отримане завдяки безперешкодному доступу до навчальних документів і вміння з ними працювати;

- що надає кожному студентові нові можливості самовдосконалення та самореалізації.

Для студентів філологічних спеціальностей повною мірою застосовуються і виправдовуються на практиці всі ті етапи, фактори, характерні властивості процесу соціалізації, що і до представників інших спеціальностей студентської молоді. Однак, за наявності всіх структурних елементів складної парадигми 
входження в соціум багатогранного вузівського простору, вирізняються й суттєві відмінності, особливості з урахуванням філологічної специфіки.

Так, розробку особливостей структури соціалізації студентів філологічних спеціальностей необхідно розглядати як своєрідний синтез психологопедагогічних, соціологічних доробок у комплексі з новітніми досягненнями гуманітарних наук. Зважаючи на думку О. Усик (2010), до компетентності майбутнього філолога необхідно долучити:

- розвиток світогляду та підготовку до сприйняття себе як носія національних цінностей, до взаємозв'зку за допомогою мови у пошуку вирішення глобальних проблем;

- розвиток загальнолюдських культурних цінностей, космополітичного мислення, усвідомлення відповідальності за майбуття країни;

- навчання етично прийнятних норм самовираження в суспільстві;

- оволодіння етикою і стратегією дискусійного спілкування з людьми різних поглядів і вірувань;

- набуття та розвиток умінь застосовувати соціокультурні знання, уміння і навички відповідно до ситуації спілкування у процесі комунікації;

- розвиток потреби в самоосвіті.

Сфера освіти в сучасних умовах проявляє себе як найбільш динамічна соціальна підсистема, що відтворює моделі соціалізації. Освіта активно реагує на соціально-комунікаційні трансформації, значення яких посилюють інформатизація, диференціація, поява нового ринку освітніх послуг.

Загалом будь-яку спеціальність, яку пропонує вища школа, слід розглядати як максимально наближену можливість розвитку та реалізації здібності особистості, ऑiі інтелектуального та творчого потенціалу. Спеціальності, пов’язані $з$ професійною підготовкою майбутніх філологів, передбачають комплексну взаємодію соціальних, навчальних, виховних та дидактичних, цифрових компонентів разом із наповненням їх новим змістом.

Соціалізація майбутнього вчителя-філолога - це складний цілісний стан соціалізації особистості, який характеризується сукупністю іiі професійно важливих якостей і забезпечує їй свідомий перехід із системи вузівської підготовки в систему професійної діяльності та успішну самореалізацію в ній на основі ціннісного ставлення до педагогічної праці, володіння способами самопізнання, самоаналізу i самооцінки, прагнення до самоосвіти та самовиховання, здійснення самоконтролю і самокорекції, наявності професійних здібностей, педагогічних та філологічних. Аналіз численних концепцій соціалізації показує, що усі вони так чи інакше тяжіють до двох підходів, які різняться розумінням ролі самої людини в процесі соціалізації. 
Перший підхід передбачає пасивну позицію людини в процесі соціалізації, а саму соціалізацію розглядає як процес адаптації його до суспільства, яке формує кожного члена суспільства у відповідності з культурою, яка йому притаманна. Другий підхід передбачає активну участь людини в процесі соціалізації, коли людина не тільки адаптується до суспільства, але й впливає на свої життєві обставини й на самого себе. Цей підхід можна визначити як суб'єкт - суб’єктні. Спираючись на цей підхід, соціалізацію можна трактувати як розвиток і самозміну людини в процесі засвоєння та відтворення культури, що відбувається у взаємодії людини з умовами життя на усіх етапах.

Для успішної соціалізації студентів необхідно увести у практику нові, відповідні вимогам інформаційного суспільства, методи роботи, що спираються на сучасні педагогічні теорії й актуальні методологічні принципи, в тому числі цифровий контент. У нових історичних умовах університету необхідно повернути роль найважливішого інституту соціалізації, визначити шляхи вирішення задач підготовки студента до успішної діяльності в рамках нової системи соціальних відносин, обумовлених законами ринку, з одного боку, 3 іншого - цінностями культури постіндустріального цифрового суспільства.

Соціалізація студентів - майбутніх філологів має специфічні ознаки. Ціннісні орієнтації у поєднанні із соціальними нормами складають певну систему поведінки молоді, яка контролюється з боку керівництва закладу вищої освіти, оточуючим середовищем, суспільством. Тому, за нашим переконанням, виникає потреба у створенні соціально-комунікаційного простору, в якому буде відбуватися процес соціалізації і складником якого буде цифровий контент.

Зазвичай, кінцевою метою підготовки фахівців вважається сформованість професійних компетентностей, але не враховується рівень соціалізації, що теж $\epsilon$, за нашим переконанням, дуже важливим. Хоча процес соціалізації студентів не виділяється в окремий напрям професійної підготовки, завдання щодо цього аспекту становлення особистості майбутнього філолога повинні реалізовуватися принаймні у навчально-виховному процесі. Можна зробити висновок про те, що процес соціалізації студентів залишається поза увагою закладів вищої освіти, хоча саме він відіграє значну роль у майбутній практичній діяльності вчителя. Вважаємо доцільним введення додаткових форм навчально-виховної роботи, котрі дозволять сприяти процесу соціалізації майбутніх студентів-філологів. Для забезпечення ефективного проходження процесу соціалізації навчальна та виховна робота повинні здійснюватися з врахуванням специфіки спеціалізації студентів-філологів та їх майбутньої педагогічної діяльності і характеризуватися творчим підходом до його організації та враховувати специфіку спеціалізації. 
Роль цифрового контент-навчання в соціалізації студентів-майбутніх філологів

Але цифровізація вищої освіти - процес складний і неоднозначний. Цифровізація, на думку українських дослідників, має зворотний бік, що треба враховувати під час планування трансформацій. Вчені вказують на реальне зниження статусу університетських дипломів в умовах відкритого і мережевого навчання, на фактичне зростання навантаження викладача в умовах цифровізації освіти, яке поки нормативно не враховується у системі нормування оплати праці. Крім того, нівелюється функція соціалізації здобувачів освіти, які переважно випадають 3 мікросоціуму закладу вищої освіти та індивідуалізуються в цифровому середовищі. Виникають потенційні загрози руйнування традиційної моделі освіти, що відображається у знеціненні гуманітарного знання у процесах цифровізації освіти й економіки.

Висновки 3 дослідження і перспективи подальших розвідок у цьому напрямі. Результатом нашого дослідження стало вивчення засобів комунікації, створення гармонійного соціально-комунікаційного простору 3 метою соціалізації студентів. Саме від рівня соціалізації студента, зокрема, філолога як майбутнього фахівця значною мірою залежить успішне виконання соціального замовлення держави на підготовку фахівців з високим рівнем соціалізації особистості. В цьому контексті застосування цифрового контент-навчання дозволить вийти на системний рівень пізнання дійсності, бачити i використовувати механізми соціалізації особистості, в чому і будуть полягати перспективи подальших розвідок у цьому напрямі.

\section{СПИСОК ВИКОРИСТАНИХ ДЖЕРЕЛ}

1. Андрущенко, В. (2005). Освіта в діалозі цивілізацій: зростання комунікативної функції освіти. Освіта і управління, 8(1), 18-19.

2. Грабар, Н. Г. (2012). Мультимедійні технології та їхній вплив на комунікацію в освіті. Вісник Книжкової палати, 6, 20 - 22.

3. Лапінський, В. В. (2010). Засоби інформаиійно-комунікаиійних технологій єдиного інформаційного простору системи освіти України. Київ: Педагогічна думка.

4. Пилипенко, О. І. (2012). Комунікативні ефекти соціальної роботи. Світ соиіальних комунікаиій. Київ: КиМУ.

5. Почепцов, Г. Г. (2010). Соціальні і нові комунікативні технології. Комунікаиія. 2010. № 1.19-26.

6. Сидоренко, О. Л. (2004). Соиіальна педагогіка як наука. Харків: ХНУ ім. B. М. Каразіна.

7. Усик, О. Ф. (2010). Формування соціокультурної компетентності студентів філологічних спечіальностей у прочесі вивчення гуманітарних дисциплін (дис. канд. пед. наук.). Київ, Україна: Інститут педагогіки АПН.

8. Шелестова, А. М. (2013). Характеристика сучасного інтегрованого інформаційнокомунікаційного простору вищого навчального закладу. Вісник ХДАК, 39, 235 - 241.

\section{THE ROLE OF DIGITAL CONTENT LEARNING IN THE SOCIALIZATION OF STUDENTS-FUTURE PHILOLOGISTS}

(ㄷ ДВНЗ «Донбаський державний педагогічний університет» 


\author{
Valentyna Kovalenko \\ the Senior Lecturer of the Department of Foreign Languages, \\ SHEI "Donbass State Pedagogical University", \\ Sloviansk, Ukraine \\ ORCID 0000-0002-7391-3746 \\ valentina.kovalenko1204@gmail.com
}

\begin{abstract}
The problem to which the article is devoted is the discrepancy between the increasing requirements for efficiency and accelerating the socialization of the individual and insufficient use of the interaction of social and communication space of higher education, its digital component and its insufficient implementation into practice. The problems of digitalization of higher pedagogical education, various aspects of digital content learning, the formation of the digital culture as a phenomenon of the information society have found its significant place in the scientific works of L. Havrilova, O. Krapivenko, T. Brown. R. Martin, D. Rawls.

In recent years, scientific research has represented a number of issues related to the problem of our study, in particular: the formation of the information culture (digital, information digital). The subject of our study is the digital content-learning and its role in the socialization of the students of Philology. The purpose of the study is to substantiate the necessity to use the digital content learning as a component of socialization in the training of philologists-to be.

The results of the scientific work show that the digital content learning involves the ability to use digital technologies to support social integration, active citizenships, creativity, collaboration with other people and achieve personal and social goals. The specific parallel digital space (electronic form of communication) is a feature of communication processes that take place in the social and communication space of higher education. It determines the virtuality of communication processes, when the electronic communication, in contrast to oral or documentary forms of communication, takes place in the virtual information space of global computer network. The conclusions are: the use of the digital content learning will reach a the systemical level of the knowledge of reality helps to watch and use the mechanisms of individual's socialization.
\end{abstract}

Key words: digitalization of education; process of socialization; higher education.

\title{
REFERENCES
}

1. Andrushchenko, V. (2005). Education in the Dialogue of Civilizations: the Growth of the Communicative Function of Education. Education and Management, 8 (1), 18-19.

2. Hrabar, N. H. (2012). Multimedia Technologies and Their Impact on Communication in Education. Bulletin of the Book Chamber, 6, 20-22.

3. Lapinskyi, V. V (2010). Means of Information and Communication Technologies of the Single Information Space of the Education System of Ukraine. Kyiv, Ukraine: Pedagogical thought.

4. Pylypenko, O. I. (2012). Communicative Effects of Social Work. The World of Social Communications. Kyiv, Ukraine: Kyiv National Medical University.

5. Pocheptsov, H. H. (2010). Social and New Communication Technologies. Communication, 1, 19-26.

6. Sydorenko, O. L. (2004). Social Pedagogy as a Science. Kharkiv, Ukraine: KhNU.

7. Usyik, O. F. (2010). Formation of Socio-cultural Competence of Students of Philological Specialties in the Process of Studying Humanities. (PhD dissertation). Kyiv, Ukraine: Institute of Pedagogy of the Academy of Pedagogical Sciences.

8. Shelestova, A. M. (2013). Characteristics of the Modern Integrated Information and Communication Space of the Higher Educational Institution. Bulletin of the KhDAK, 39, 235 -241.

Матеріали надійшли до редакції 17.09.2021 p.

Професіоналізм педагога: теоретичні й методичні аспекти. Методичні матеріали до проєкту «Цифровий освітній простір: українсько-польський досвід». - Слов’янськ, 2021. 